\title{
Regulation of fibronectin gene expression by cyclic AMP and phorbol myristate acetate in HT-1080 human fibrosarcoma
}

\author{
Byung-Heon Lee ${ }^{1}$, Rang-Woon Park ${ }^{2}$ and \\ In-San Kim², 3 \\ 1 Department of Biochemistry, School of Medicine, \\ Dongguk University, Kyungju 780-714, Korea \\ 2 Department of Biochemistry, School of Medicine, \\ Kyungpook National University, Taegu 700-422, Korea \\ 3 Corresponding author \\ Accepted 26 October 1998
}

Abbreviations: FN, fibronectin; CRE, CAMP-responsive element; PKC, protein kinase C; MEM, minimal essential medium; BSA, bovine serum albumin; PMA, phorbol-12myristate-13-acetate; $\mathrm{Bt}_{2} \mathrm{CAMP}$, dibutyryl cAMP
(Dean et al. , 1988; Nakajima et al., 1992; Taylor et al., 1992; Jordan-Sciutto et al., 1997). The cAMP pathway has been shown to be an important signaling pathway involved in FN expression (Dean et al., 1988, 1989). It has been reported to activate the transcription of $F N$ gene through the cAMP-responsive element (CRE) in FN promoter (Dean et al., 1989; Bowlus et al., 1991). The protein kinase $C$ (PKC) pathway, another important signaling pathway, has also been shown to regulate FN expression (Cagliero et al., 1991; Studer et al., 1993; Lee et al., 1996).

Regulation of FN expression by cAMP and PKC pathways show different patterns depending on cell type. Cyclic AMP stimulates FN synthesis in fibrosarcoma cells but inhibits it in granulosa cells (Dean et al., 1988; Dean et al., 1989; Bernath et al., 1990). Phorbol-12myristate-13-acetate (PMA), a PKC activator, stimulates FN expression in lung fibroblasts and renal mesangial cells but inhibits it in endothelial cells (Cagliero et al., 1991; Studer et al., 1993; Lee et al., 1996). These reports suggest cell-type specific regulation of $\mathrm{FN}$ expression. In addition, cAMP and PKC pathways show synergistic or antagonistic interactions in the regulation of the expression of cellular genes including the FN gene. Cyclic AMP and PMA interact synergistically to regulate the expression of the chorionic gonadotropin gene in choriocarcinoma cells (Anderson et al., 1988). Cyclic AMP inhibits the PKC-induced stimulation of FN expression in human lung fibroblasts, while it alone has no effect (Lee et al., 1997). In this regard, we studied the regulation of $\mathrm{FN}$ gene expression by CAMP and PMA and their interaction in HT-1080 human fibrosarcoma cells in which FN expression has been reported to be induced by cAMP (Dean et al., 1988; Dean et al., 1989).

\section{Materials and Methods}

\section{Cell cultures}

A human fibrosarcoma cell line HT-1080 (ATCC CCL 121) was obtained from the American Type Culture Collection. Cells were cultured in minimal essential medium (MEM) supplemented with $10 \%$ fetal bovine serum (Gibco/BRL), $100 \mathrm{U} / \mathrm{ml}$ of penicillin, $100 \mu \mathrm{g} / \mathrm{ml}$ of streptomycin, and $0.1 \%$ nonessential amino acids. Cells were incubated at $37^{\circ} \mathrm{C}$ in a $5 \% \mathrm{CO}_{2}$ air environment.

\section{Enzyme-linked immunosorbent assay (ELISA) of FN}

Confluent cells in 24-well culture plates were incubated with serum-free MEM containing $1 \%$ bovine serum albumin 
(BSA) and the indicated reagents. The cell layer FN was extracted using a lysis buffer containing $10 \mathrm{mM}$ Tris$\mathrm{HCl}, \mathrm{pH} 7.4,0.15 \mathrm{M} \mathrm{NaCl}, 1 \%$ Nonidet P-40, $1 \%$ sodium deoxycholate, $0.5 \%$ SDS, $1 \mathrm{mM}$ EDTA and 1 $\mathrm{mM}$ PMSF. The total amount of FN in the medium and cell layer was determined by ELISA and then normalized by the cellular DNA content measured by fluorophotometric assay as described previously (Kim et al., 1992). Microtiter plates were coated with $100 \mathrm{ng}$ of purified human plasma FN. The first antibody was a 1:800 dilution of goat anti-human FN antibody (Sigma). The second antibody was a 1:3,000 dilution of horseradish peroxidase-conjugated rabbit anti-goat IgG (Sigma). The enzyme substrate was ophenylenediamine, and the absorbance was read at $492 \mathrm{~nm}$. The standard curve using purified human plasma $\mathrm{FN}$ was linear between $30 \mathrm{ng}$ and $300 \mathrm{ng}$.

\section{Radioactive labeling and immunoprecipitation of FN}

Confluent cells in 35-mm culture dishes were incubated with serum-free MEM containing $1 \% \mathrm{BSA}$ and reagents and then labeled for $2 \mathrm{~h}$ with methionine-free MEM containing $30 \mu \mathrm{Ci} / \mathrm{ml}\left[{ }^{35} \mathrm{~S}\right]$ methionine (Amersham) and the corresponding reagents. The medium was collected and the cell layer FN was extracted with a lysis buffer as described above. Immunoprecipitation of $\mathrm{FN}$ from the combined samples of medium and cell layer extracts containing equal amounts of radioactive total protein was performed as described previously (Lee et al., 1996). An excess ( $3 \mu \mathrm{g})$ of goat anti-human FN antibody was added to the combined samples of medium and cell layer extracts containing the same amounts of radioactivity and then incubated at $4^{\circ} \mathrm{C}$ for $1-2 \mathrm{~h}$. The immune complexes were incubated with $30 \mu \mathrm{l}$ of protein A-sepharose beads (Pharmacia) for 1 hour. Sepharose beads and adsorbed proteins were solubilized in $30 \mu \mathrm{l}$ of an electrophoresis sample buffer by heating at $100^{\circ} \mathrm{C}$ for $4 \mathrm{~min}$. Samples containing the isolated $\mathrm{FN}$ were analyzed either by SDS-PAGE using a $6 \% \mathrm{gel}$ and subsequent fluorography or by counting the radioactivity (cpm) of the solution with a $\beta$-counter.

\section{Northern blot hybridizations}

Confluent cells in 100-mm culture dishes were incubated with serum-free MEM containing $1 \%$ BSA and reagents. Total cellular RNA was isolated with acid guanidinium thiocyanate-phenol-chroloform, fractionated by electrophoresis on a $0.8 \%$ agarose gel containing $2.2 \mathrm{M}$ formaldehyde, transferred to a nylon membrane, and hybridized with a cDNA probe as described previously (Sambrook et al., 1989). The cDNA probe was labeled with $\left[\alpha^{32} P\right]$ dCTP (Amersham) using a megaprime DNA labeling system (Amersham). FH1 human FN cDNA (Kornblihtt et al., 1983) and pHcGAP human glyceraldehyde-3- phosphate dehydrogenase cDNA (Tso et al., 1985) were used as probes.

\section{Plasmid constructions}

To construct the plasmid pGL2F1900 containing DNA sequences from -1908 to +136 of the rat $F N$ gene fused to the luciferase reporter gene, the plasmid pF1900CAT containing the same DNA sequences fused to the CAT gene (provided by Dr. Kinichiro Oda, Science University of Tokyo) was cleaved with Pstl. The $2.1 \mathrm{~kb}$ Pstl fragment of the FN gene was inserted into the Pstl site of pBluescript II KS(-) (Stratagene) to generate pBS-F1900. Finally, the insert was cleaved with BamHI-Hindll from pBS-F1900 and inserted into the Bg/ll-HindIII site of pGL2-Basic vector (Promega) to generate pGL2F1900.

\section{Transient and stable transfection of DNA}

DNA transfection was performed by using the $\mathrm{CaPO}_{4}$ precipitation method modified by Chen and Okayama (Chen and Okayama, 1987). Cells $\left(4 \times 10^{5}\right.$ cells per dish) were plated the day before transfection onto 100 $\mathrm{mm}$ culture dishes and grown to an approximate $70 \%$ confluence. Cells were transfected with $4 \mu \mathrm{g}$ of pGL2F $1900,1 \mu \mathrm{g}$ of pSV $\beta$-gal as an internal control, and $3 \mu \mathrm{g}$ of pGL2-Basic vector as a carrier. After incubation with the DNA precipitate for $5 \mathrm{~h}$ and subsequently with $15 \%$ glycerol for $2 \mathrm{~min}$, cells were recovered overnight with a fresh medium containing $10 \%$ serum. Cells were then incubated with each reagent in a medium containing $0.5 \%$ serum for $24 \mathrm{~h}$ and harvested at $48 \mathrm{~h}$ from the start of transfection. For stable transfection, cells grown in $60-\mathrm{mm}$ culture dishes were transfected with $7 \mu \mathrm{g}$ of pGL2F1900, $0.7 \mu \mathrm{g}$ of pSV $\beta$-gal, and $0.7 \mu \mathrm{g}$ of pSVNeo as a selection marker. Transfected clones were selected by subculture in a medium containing $400 \mu \mathrm{g} / \mathrm{ml}$ of geneticin (GIBCO/BRL). All selected clones were pooled and used for the following experiments.

\section{Luciferase and $\beta$-galactosidase assays}

Cells were lysed with $250 \mu \mathrm{l}$ of a lysis solution (100 mM potassium phosphate, $\mathrm{pH} 7.8,0.2 \%(\mathrm{v} / \mathrm{v})$ Triton X-100, and $1 \mathrm{mM}$ dithiothreitol (DTT)). For luciferase assays, $100 \mu \mathrm{l}$ of the cell lysates were mixed with $500 \mu \mathrm{l}$ of a luciferase assay buffer (15 $\mathrm{mM}$ potassium phosphate, $\mathrm{pH} 7.8,25 \mathrm{mM}$ glyglycine, $\mathrm{pH} 7.8,15 \mathrm{mM} \mathrm{MgSO}_{4}, 4 \mathrm{mM}$ EGTA, $2 \mathrm{mM}$ ATP, and $1 \mathrm{mM}$ DTT). The reaction mixture was incubated with $100 \mu \mathrm{l}$ of a luciferase assay buffer containing $100 \mu \mathrm{M}$ luciferin (Analytical luminescence laboratory) and luminescence was measured by using a luminometer (Berthold). For $\beta$ galactosidase assays, $10 \mu \mathrm{l}$ of the cell lysates were used and activity was measured with a Galacto-Light ${ }^{\mathrm{TM}}$ chemiluminesent reporter assay system (Tropix) according to the manufacturer's directions. 


\section{Results}

Treatment of HT-1080 cells for $24 \mathrm{~h}$ with dibutyryl cAMP ( $\left.\mathrm{Bt}_{2} \mathrm{CAMP}\right)$, a cAMP analogue, increased $\mathrm{FN}$ synthesis in a dose-dependent manner with a maximum 3.5-fold increase, whereas treatment with PMA, a PKC activator,
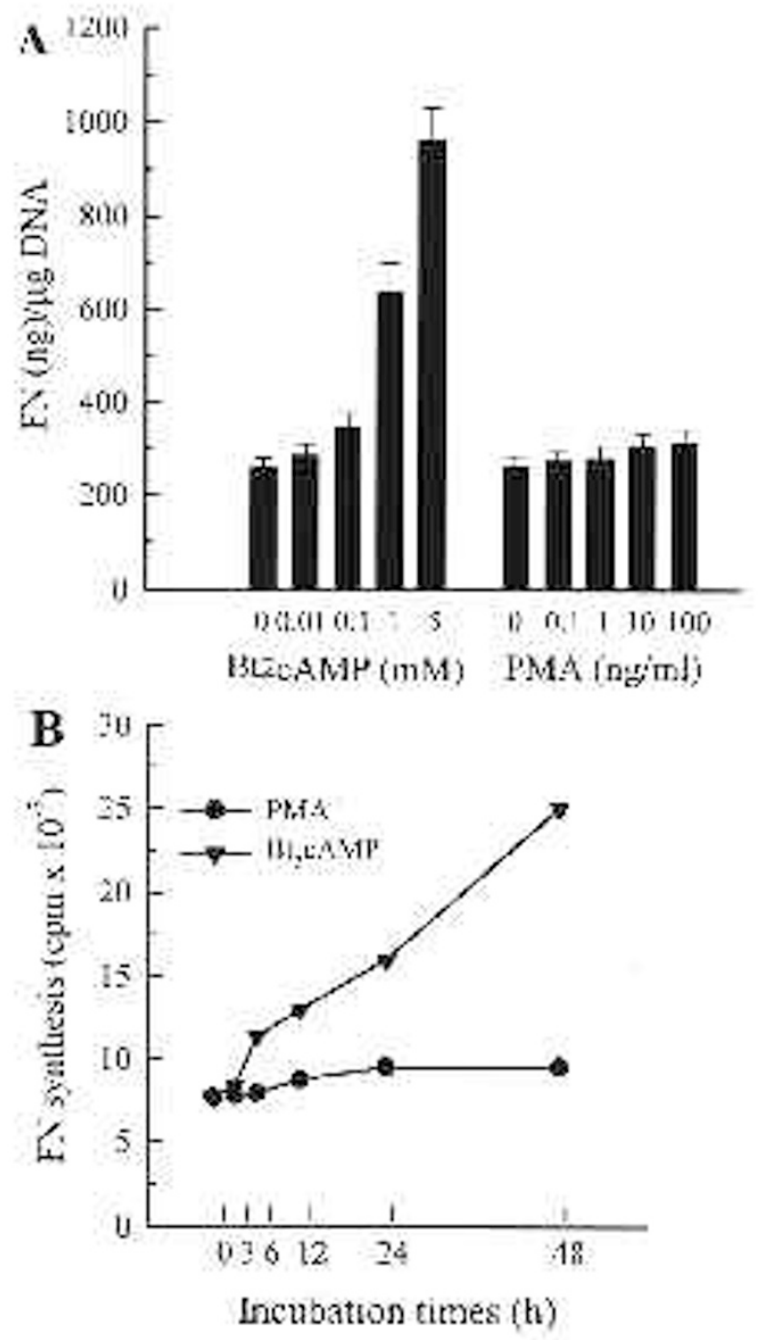

Figure 1. Dose- and time-response of $\mathrm{FN}$ synthesis by $\mathrm{Bt}_{2} \mathrm{CAMP}$ and $\mathrm{PMA}$ in $\mathrm{HT}-1080$ cells. (A) Confluent cells were incubated with various concentrations of either $\mathrm{Bt}_{2} \mathrm{CAMP}$ or PMA for $24 \mathrm{~h}$. FN synthesis was determined by measuring the total amount of $\mathrm{FN}$ in the medium and cell layer extracts by ELISA and then normalizing it with the cellular DNA content. Data are given as a mean \pm S.D. of four different samples. (B) Confluent cells were incubated with either $\mathrm{Bt}_{2} \mathrm{CAMP}(1 \mathrm{mM})$ or PMA (100 $\left.\mathrm{ng} / \mathrm{ml}\right)$ for the indicated periods of time and then labeled with $30 \mu \mathrm{Ci} / \mathrm{ml}\left[{ }^{35} \mathrm{~S}\right]$ methionine $(1,000 \mathrm{Ci} / \mathrm{mmol})$ for 2 h. FN was isolated by immunoprecipitation from the combined fractions of the medium and cell layer extracts containing equal amounts $\left(5 \times 10^{6} \mathrm{cpm}\right)$ of radioactive total protein. Samples containing the isolated FN were analyzed by counting the radioactivity (cpm) of the solution with a $\beta$-counter. did not affect FN synthesis at any concentration tested (Figure 1A). To examine the time-course of FN synthesis, cells were treated for various periods of time with either $1 \mathrm{mM} \mathrm{Bt}_{2} \mathrm{cAMP}$ or $100 \mathrm{ng} / \mathrm{ml}$ PMA. $\mathrm{Bt}_{2} \mathrm{cAMP}$ increased FN synthesis time-dependently from 3 hours to $48 \mathrm{~h}$, while PMA did not (Figure 1B). The effect of these reagents on FN synthesis does not seem to be a nonspecific effect on total protein synthesis, since neither $\mathrm{Bt}_{2} \mathrm{CAMP}$ nor PMA affect total protein synthesis (data not shown).

To study the interaction between CAMP and PMA, cells were treated for $48 \mathrm{~h}$ with $\mathrm{Bt}_{2} \mathrm{CAMP}$ and PMA in combination. PMA inhibited the $\mathrm{Bt}_{2} \mathrm{CAMP}$-induced stimulation of FN synthesis, but when used alone had no effect (Figure 2A). To test whether the regulation by cAMP and PMA occurs at the mRNA levels, the steadystate levels of FN mRNA were determined. In agreement with the results of $\mathrm{FN}$ synthesis, $\mathrm{Bt}_{2} \mathrm{CAMP}$ increased $\mathrm{FN}$ mRNA levels, while PMA inhibited the $B t_{2} \mathrm{CAMP}$ induced increase of FN mRNA levels (Figure 2B).

To investigate the regulation of $\mathrm{FN}$ expression by CAMP and PMA and their interaction at the transcriptional level, the plasmid containing $1900 \mathrm{bp}$ of $\mathrm{FN}$ promoter fused to the luciferase reporter gene was transiently transfected into HT-1080 cells. Bt ${ }_{2}$ cAMP increased the $\mathrm{FN}$ promoter activity by 4.5 -fold, while

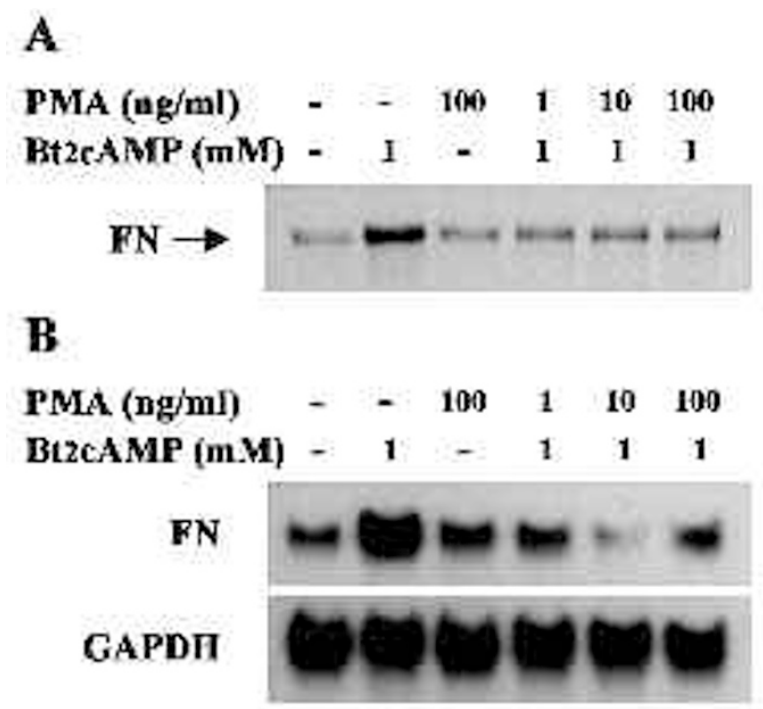

Figure 2. Inhibition of $\mathrm{Bt}_{2} \mathrm{CAMP}$-induced stimulation of $\mathrm{FN}$ synthesis and mRNA levels by PMA in HT-1080 cells. (A) Confluent cells were incubated with $\mathrm{Bt}_{2} \mathrm{CAMP}$ or PMA for $48 \mathrm{~h}$ and then labeled with $30 \mu \mathrm{Ci} / \mathrm{ml}\left[{ }^{35} \mathrm{~S}\right]$ methionine $(1,000 \mathrm{Ci} / \mathrm{mmol})$ for $2 \mathrm{~h}$. FN was isolated by immunoprecipitation from the combined fractions of the medium and cell layer extracts containing equal amounts $\left(5 \times 10^{6} \mathrm{cpm}\right)$ of radioactive total protein. The isolated FN was analyzed by SDS-PAGE and fluorography. The arrow indicates the location of FN (Mr. $=220-240 \mathrm{kDa})$. (B) Total RNA was isolated and $30 \mu \mathrm{g}$ of each sample were subjected to electrophoresis and analyzed by Northern blot hybridization. GAPDH, glyceraldehyde-3-phosphate dehydrogenase. 


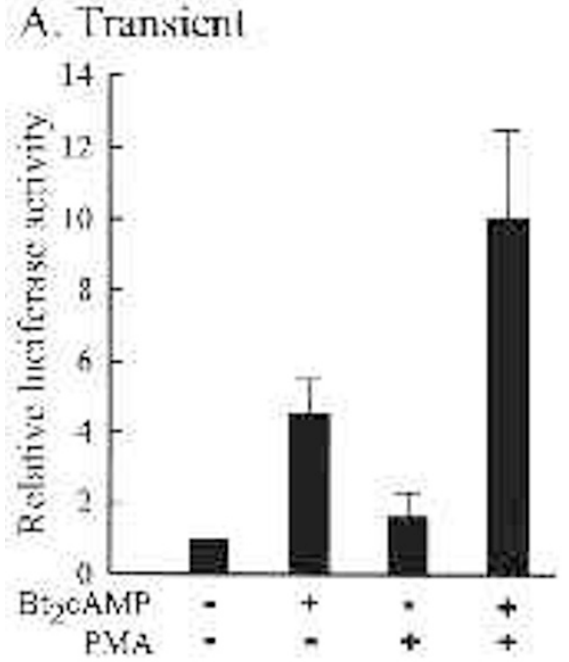

B. Stable

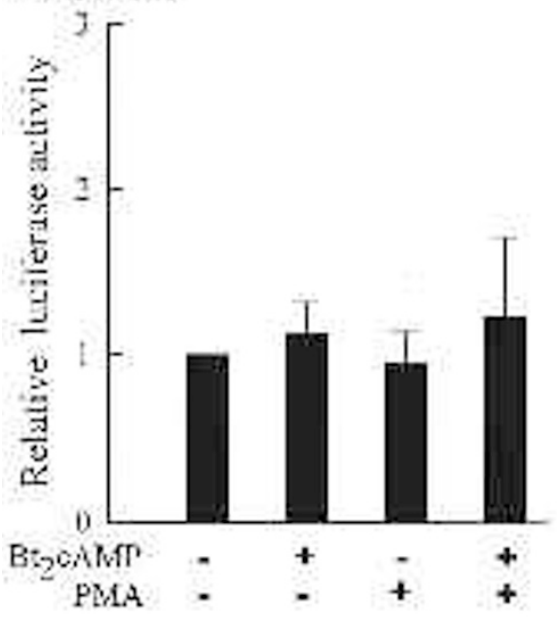

Figure 3. Effect of $\mathrm{Bt}_{2} \mathrm{CAMP}$ and PMA on the activity of transiently and stably transfected FN promoter in HT-1080 cells. (A) Cells were transfected with $4 \mu \mathrm{g}$ of pGL2F1900, $1 \mu \mathrm{g}$ of pSV $\beta$-gal, and $3 \mu \mathrm{g}$ of pGL2-Basic vector as described in 'Methods and Materials'. After $48 \mathrm{~h}$ of treatment with $\mathrm{Bt}_{2} \mathrm{CAMP}$ (1 mM) and PMA (100 $\mathrm{ng} / \mathrm{ml})$, cells were harvested and the luciferase activity was measured and normalized by $\beta$-galactosidase activity to correct transfection efficiency. Each bar represents promoter activity expressed relatively to the control value. Data are given as a mean \pm S.D. of three different experiments. (B) Cells were transfected with $7 \mu \mathrm{g}$ of pGL2F1900, $0.7 \mu \mathrm{g}$ of pSV $\beta$-gal, and $0.7 \mu \mathrm{g}$ of pSVNeo and then stably transfected cells were selected by culturing in the presence of $400 \mu \mathrm{g} / \mathrm{ml}$ of geneticin. Stably transfected cells were treated with $\mathrm{Bt}_{2} \mathrm{CAMP}(1 \mathrm{mM})$ and PMA $(100 \mathrm{ng} / \mathrm{ml})$ for $48 \mathrm{~h}$ and the activities of luciferase and $\beta$-galactosidase were determined. Each bar represents promoter activity expressed relatively to the control value. Data are given as a mean \pm S.D. of three different experiments.

PMA alone did not show any significant effect (Figure 3A). PMA, on the contrary to its inhibitory effect on the cAMP-induced FN synthesis and mRNA levels, enhanced the cAMP-induced FN promoter activity up to 10-fold (Figure 3A).
Since the effect of PMA on the CAMP-induced transiently transfected promoter activity was different from that of PMA on the cAMP-induced FN synthesis and mRNA levels, stable transfection experiments were performed. However, neither $\mathrm{Bt}_{2} \mathrm{CAMP}$ nor PMA affected stably transfected FN promoter activity (Figure $3 \mathrm{~B}$ ). The combined treatment of PMA and $\mathrm{Bt}_{2} \mathrm{CAMP}$ did not affect stably transfected promoter activity, either (Figure 3B).

\section{Discussion}

This study shows that PMA antagonizes cAMP-induced $\mathrm{FN}$ gene expression and that both the induction of $\mathrm{FN}$ gene expression by cAMP and the inhibition of CAMP action by PMA may occur at the posttranscriptional level in HT-1080 human fibrosarcoma cells. Cyclic AMP stimulated $\mathrm{FN}$ synthesis and mRNA levels and the activity of a transiently transfected FN promoter, but had no effect on the activity of a stably transfected promoter. The discrepancy between the protein/mRNA levels and the promoter activity suggests that cAMP probably stimulates $\mathrm{FN}$ expression through posttranscriptional regulation in HT-1080 cells. PMA inhibited the cAMPinduced $\mathrm{FN}$ synthesis and mRNA levels but enhanced the cAMP-induced transiently transfected FN promoter, while having no effect on the stably transfected promoter. The differential effect of PMA on CAMP-induced FN protein/mRNA levels and promoter activity suggests that the PMA-induced signaling pathway antagonistically interacts with the CAMP pathway in regulating $\mathrm{FN}$ expression probably at the posttranscriptional level in HT-1080 cells.

Synergistic or antagonistic interactions between cAMP and PMA on the FN expression depending on cell-types have been reported (Anderson et al., 1988; Lee et al., 1997). Previously it has been shown that cAMP alone has no effect on FN expression but inhibits the PMAinduced stimulation of $\mathrm{FN}$ expression in lung fibroblasts (Lee et al., 1997). The present study, on the contrary, shows that PMA alone has no effect on FN expression but inhibits the CAMP-induced stimulation of FN expression in HT-1080 fibrosarcoma cells. The mechanism of the cell-type specific regulation of $\mathrm{FN}$ expression is still unknown.

Cyclic AMP has been reported to stimulate FN expression by activating transcription possibly through the CRE site at -170 and two putative CRE-like sites at -260 and -415 in FN promoter, based on the results of transient transfection experiments in HT-1080 cells (Dean et al., 1989; Bowlus et al., 1991). In agreement with the previous reports (Dean et al., 1989; Bowlus et al., 1991), this study shows that cAMP stimulates the activity of transiently transfected FN promoter. This study, however, shows that CAMP has no effect on the activity of stably transfected FN promoter. Several possible explanations could be considered for the discrepancy in the promoter activity 
in transient and stable transfections. One of them is that the transient transfection in which the target gene is in an episomal state and the stable transfection in which the target gene is integrated into cellular chromatin may have different general transcription factor requirements or rate-limiting steps for transcription (Natesan et al., 1997). Whatever the mechanism, the promoter activity in stable transfection would reflect more physiological situation than that in transient transfection. In fact, the results of this study show that PMA enhances the CAMP. induced $\mathrm{FN}$ promoter activity in transient transfection assays that is quite opposite to its inhibitory effect on cAMP-induced FN protein synthesis and mRNA levels. In this regard, it is unlikely that the results of transient transfection reflect the endogenous FN expression, at least in HT-1080 cells.

It has been shown that the deletion of CRE at -170 does not eliminate the CAMP-responsiveness of FN promoter (Bowlus et al., 1991). Furthermore, the FN CRE (-170)binding factor that cooperates with the adjacent CCAAT box-binding protein to stimulate $\mathrm{FN}$ transcription in the liver has been shown to be an heterodimer of a 43-kDa protein and ATF-2 (Muro et al., 1992; Srebrow et al., 1993). ATF-2 itself lacks a constitutive activating domain but interacts with transcriptional activators like adenovirus E1A and HTLV-1 Tax, recruiting these factors to CRE-containing promoters (Liu and Green, 1990). ATF-2, however, has been shown to be a CAMPindependent transcription factor, unlike the CAMPdependent trans-cription factor CREB (Flint and Jones, 1991). Taken together, contrary to previous reports, cAMP may stimulate $\mathrm{FN}$ expression, not by activating the transcription of the FN gene, but by acting through a posttranscriptional mechanism in HT-1080 cells.

Posttranscriptional regulation of the $\mathrm{FN}$ expression in HT-1080 cells has been observed in other conditions. The basal levels of FN synthesis and mRNA are lower in HT-1080 cells than in nontumorigenic revertants of the cells in which the mutated N-ras oncogene is underexpressed, whereas $\mathrm{FN}$ promoter is more active in HT-1080 cells than in revertant cells (Chandler and Bourgeois, 1991; Chandler et al., 1994). Transforming growth factor- $\beta$ and dexamethasone increase $F N$ synthesis in HT-1080 cells partly through increasing the stability of FN mRNA (Dean et al., 1988). Possible mechanism(s) of the posttranscrip-tional regulation of FN expression observed in this study may include an alteration in the cytoplasmic stability of FN mRNA and/or in the alternative splicing of FN mRNA by CAMP or PMA. Further studies including nuclear run-on assays would be required to obtain more direct evidence for the posttranscriptional regulation and understanding of its possible mechanisms.

\section{Acknowledgements}

This work was supported by Grant BSRI 97-4403 (to I.S. K.) and Grant 1997-003-F00014 (to B.-H. L.) from the Korea Research Foundation of the Ministry of Education made in the program year of 1997 . We thank Dr. Kinichiro Oda (Science University of Tokyo) for providing the pF1900CAT plasmid.

\section{References}

Andersen, B., Milsted, A., Kennedy, G. and Nilson, J. H. (1988) Cyclic AMP and phorbol esters interact synergistically to regulate expression of the chorionic gonadotropin genes. J. Biol. Chem. 263: 15578-15583

Bernath, V. A., Muro, A. F., Vitullo, A. D., Bley, M. A., Baranao, J. L. and Kornblihtt, A. R. (1990) Cyclic AMP inhibits fibronectin gene expression in a newly developed granulosa cell line by a mechanism that suppresses CAMP-responsive element-dependent transcriptional activation. J. Biol. Chem. 265: 18219-18226

Bowlus, C. L., McQuillan, J. J. and Dean, D. C. (1991) Characterization of three different elements in the 5 '-flanking region of the fibronectin gene which mediate a transcriptional response to CAMP. J. Biol. Chem. 266: 1122-1127

Cagliero, E., Roth, T., Roy, S., Maiello, M. and Lorenzi, M. (1991) Expres-sion of genes related to the extracellular matrix in human endothelial cells. J. Biol. Chem. 266: 1424414250

Chandler, L. A. and Bourgeois, S. (1991) Posttranscriptional down-regul-ation of fibronectin in N-ras-transformed cells. Cell Growth Differ. 2: 379-384

Chandler, L. A., Ehretsmann, C. P. and Bourgeois, S. (1994) A novel mechanism of Haras oncogene action: regulation of fibronectin mRNA levels by a nuclear posttranscriptional event. Mol. Cell. Biol. 14: 3085-3093

Chen, C. and Okayama, H. (1987) High-efficiency transformation of mammalian cells by plasmid DNA. Mol. Cell. Biol. 7: 2745-2752

Dean, D. C., Blakeley, M. S., Newby, R. F., Ghazal, P., Hennighausen, L. and Bourgeois, S. (1989) Forskolin inducibility and tissue-specific expression of the fibronectin promoter. Mol. Cell. Biol. 9: 1498-1506

Dean, D. C., Newby, R. F. and Bourgeois, S. (1988) Regulation of fibro-nectin biosynthesis by dexamethasone, transforming growth factor $\beta$, and cAMP in human cell lines. J. Cell. Biol. 106: 2159-2170

Flint, K. J. and Jones, N. C. (1991) Differential regulation of three members of the ATF/CREB family of DNA-binding proteins. Oncogene 6: 2019-2026

Hynes, R. O. (1990) Fibronectins. Springer-verlag, New-York

Jordan-Sciutto, K. L., Logan, T. J., Norton, P. A., Derfoul, A., Dodge, G. R. and Hall, D. (1997) Reduction in fibronectin expression and alteration in cell morphology are coincident in $\mathrm{NIH} 3 \mathrm{~T} 3$ cells expressing a mutant E2F1 transcription factor. Exp. Cell Res. 236: $527-536$

Kim, K.-S., Lee, B.-H. and Kim, I.-S. (1992) The measurement of fibro-nectin concentrations in human aqueous humor. Korean J. Ophtal. 6: 1-5

Kornblintt, A. R., Vibe-Pedersen, K. and Baralle, F. E. (1983) Isolation and characterization of cDNA clones for human and bovine fibronectins. Proc. Natl. Acad. Sci. USA 80: 3218-3222

Lee, B.-H., Park, R.-W., Choi, J.-Y., Ryoo, H.-M., Sohn, K.-Y. and Kim, I.-S. (1996) Stimulation of fibronectin synthesis through the protein kinase $C$ signaling pathway in normal and transformed human lung fibroblasts. Biochem. Mol. Biol. Int. 39: 895-904

Lee, B.-H., Park, R.-W., Sohn, K.-Y. and Kim, I.-S. (1997) Antagonistic regulation of protein kinase $\mathrm{C}$-induced stimulation of fibronectin synthesis by cyclic AMP in human lung fibroblasts. Biochem. Mol. Biol. Int. 43: 383-390

Liu, F. and Green, M. R. (1990) A specific member of the ATF transcription factor family can mediate transcription activation by the adenovirus E1a protein. Cell 61: 1217-1224

Muro, A. F., Bernath, V. A. and Kornblihtt, A. R. (1992) Interaction of the -170 cyclic 
AMP response element with the adjacent CCAAT box in the human fibronectin gene promoter. J. Biol. Chem. 267: 12767-12774

Nakajima, T., Nakamura, T., Tsunoda, S., Nakada, S. and Oda, K. (1992) E1Aresponsive elements for repression of rat fibronectin gene trans-cription. Mol. Cell. Biol. 12: $2837-2846$

Natesan, S., Rivera, V. M., Molinari, E. and Gilman, M. (1997) Transcrip-tional squelching re-examined. Nature 390: 349-350

Sambrook, J., Fritsch, E. F. and Maniatis, T. (1989) Molecular cloning: A laboratory manual. 2nd ed., Cold Spring Harbor Laboratory Press, New York

Srebrow, A., Muro, A. F., Werbajh, S., Sharp, P. A. and Kornblihtt, A. R. (1993) The CRE-binding factor ATF-2 facilitates the occupation of the CCAAT box in the fibronectin gene promoter. FEBS Lett. 327: 25-28

Studer, R. K., Craven, P. A. and DeRubertis, F. R. (1993) Role for protein kinase C in the mediation of increased fibronectin accumulation by mesangial cells grown in highglucose medium. Diabetes 42: 118-126
Taylor, P., Cupp, C., Diaz, A., Chowdhury, M., Khalili, K., Jimenez, S. A. and Amini, S. (1992) Activation of expression of genes coding for extra-cellular matrix proteins in tatproducing glioblastoma cells. Proc. Natl. Acad. Sci. USA 89: 9617-9621

Tso, J. Y., Sun, X.-H., Kao, T.-H., Reece, K. S. and Wu, R. (1985) Isolation and characterization of rat and human glyceraldehyde-3-phosphate dehydrogenase cDNAs: genomic complexity and molecular evolution of the gene. Nucleic. Acid. Res. 13: 24852502

Wagner, S. and Green, M. R. (1993) HTLV-1 Tax protein stimulation of DNA binding of bZIP proteins by enhancing dimerization. Science 262: 395-399 